NBER WORKING PAPER SERIES

\title{
THE VALUE OF BROADBAND AND THE DEADWEIGHT LOSS OF TAXING NEW TECHNOLOGY
}

\author{
Austan Goolsbee \\ Working Paper 11994 \\ http://www.nber.org/papers/w11994 \\ NATIONAL BUREAU OF ECONOMIC RESEARCH \\ 1050 Massachusetts Avenue \\ Cambridge, MA 02138 \\ January 2006
}

I wish to thank Jen Paniza, Shannon Hariwck and Andrew Lee for outstanding research assistance, David Genesove, two anonymous referees, Anil Kashyap, Peter Klenow, Don Fullerton, Steven Levitt, Amil Petrin, and Nick Souleles and seminar participants at Harvard, Columbia, the University of Texas, the NBER and the University of Chicago for helpful comments and to thank the Alfred P. Sloan Foundation, the National Science Foundations (SES9984567), and the American Bar Foundation for financial support. The views expressed herein are those of the author(s) and do not necessarily reflect the views of the National Bureau of Economic Research.

C2006 by Austan Goolsbee. All rights reserved. Short sections of text, not to exceed two paragraphs, may be quoted without explicit permission provided that full credit, including $\odot$ ) notice, is given to the source. 
The Value of Broadband and the Deadweight Loss of Taxing New Technology

Austan Goolsbee

NBER Working Paper No. 11994

January 2006

JEL No. H2, D6

\begin{abstract}
$\underline{\text { ABSTRACT }}$
With fixed costs of developing technology, taxes can generate large efficiency costs by slowing the rate of diffusion and these costs are not accounted for in conventional analyses. This paper illustrates this by analyzing the impact that taxes would have had on broadband Internet access at an early stage of its diffusion around the country, combining data on individual demand by area with data on supplier entry in those markets. Applying a tax to broadband in 1998 would have reduced the quantity and generate a large deadweight loss in the conventional model but when the analysis accounts for the fixed costs of entering new markets, taxes would have also delayed entry in several markets. In these places, the lost consumer surplus from delay is an additional deadweight loss and it more than doubles the estimated efficiency costs of taxation. The conventional model also dramatically understates the share of tax burden that would have been borne by customers.
\end{abstract}

Austan Goolsbee

Graduate School of Business

University of Chicago

5807 S. Woodlawn Ave

Chicago, IL 60637

and NBER

goolsbee@chicagogsb.edu 


\section{Introduction}

Despite a growing literature dealing with the importance of new goods, there has been little analysis of the whether the continued introduction of new goods has any implications for tax policy. ${ }^{1}$ This paper shows that the impact of taxes on technology diffusion has the potential to be quite significant if there are fixed costs associated with introducing the new goods. Using, as a practical example, data on the market for broadband Internet access when it first began to spread widely, the results suggest that the true deadweight cost of taxation can be several times larger and the incidence born much more by consumers than indicated by a traditional tax analysis.

The case of taxes and broadband is interesting in its own right, as well. Considerable debate arose over the Internet Tax Freedom Act and its subsequent extensions which placed a moratorium on state taxation of Internet access. Legislation currently before Congress would permanently ban taxes on internet access. The states have opposed these measures, realizing the large revenue potential of such taxation. ${ }^{2}$ On top of that, there is considerable interest on the part of policy makers and the general public in the spread of broadband and the existence of a "broadband gap" between the U.S. and countries thought to be farther along the technology frontier, as well as concern about a "digital divide" separating rich, urban people from their poorer and more rural counterparts in their use of advanced technology. ${ }^{3}$ Though the market was decidedly different in the early years of broadband than it is now, many of the same issues that faced larger markets then may apply in smaller markets

1 The recent work in Industrial Organization is discussed in Trajtenberg (1989), Bresnahan and Gordon (1997), Hausman (1999), Petrin (2002), Nevo (2003) and Goolsbee and Petrin (2004). There are a few examples of work on tariffs and new goods (Romer, 1994; Feenstra, 1995; Klenow and Rodriguez-Claire, 1997) and papers on the welfare costs of regulatory delay such as Hausman $(1997 ; 1998)$.

2 Goolsbee (2001) points out that the potential revenue from applying sales tax to Internet access probably exceeds the entire revenue loss from not enforcing sales taxes on Internet purchases. Mazerov (2003) summarizes the states' position opposing the ban on access taxes because it will deny them considerable revenues.

3 Popular discussion of the 'broadband gap' can be found in Bleha (2005) or Rosenbush et al. (2004). Academic work on the spread of Internet access and the 'digital divide' include Downes and Greenstein (1998), Hoffman and Novak (1999), Compaine (2001), and Goolsbee and Guryan (2006). There has been work on how people's use of the Internet responds to prices (see, for example, Varian, 1999, Beckart 1999, the discussions in MackieMason and Varian, 1995 or the papers in McKnight and Bailey, 1997). This literature has become less relevant for analyzing taxes on access, however, since most Internet Service Providers (ISPs) currently charge a flat monthly fee for unlimited use. Bruce et al. (2004) examine the impact of taxes on overall Internet access rates 
today.

The paper will use data on individual level demand for broadband across locations to construct market specific demand curves and use them to do an analysis of broadband taxation. The results suggest that at the time of the survey (late 1998/early 1999), the consumer surplus from broadband was about $\$ 667$ million per year in markets where it was available and that the demand was highly elastic. As a result, the deadweight loss from taxing broadband in 1998, as computed in a standard analysis, would have been quite high, at almost $200 \%$ of the revenue such a tax would have generated. The tax would have been borne about $55 \%$ by consumers.

Looking deeper, however, the paper is able to use the computed producer surplus in each market to estimate the implied size of the fixed costs of entering a new market (or at least of entering on the more limited scale that characterized entry at that time). It then shows that in several medium sized markets, applying a tax on broadband would have reduced the potential producer surplus enough that suppliers would not be able to cover their fixed costs and would choose to delay the diffusion of broadband in those markets. By doing so, however, the tax would have eliminated the entire potential consumer surplus from those markets (as well as the firm profits) in the interim. Those losses are pure deadweight loss (DWL) and are large. Taking account of the impact of taxes on the spread of the new technology more than doubles the estimated DWL from the tax as compared to the standard model. The incidence of the tax is also substantially more heavily born by the consumer than in the conventional calculation.

The paper proceeds in six sections. Section 2 presents an overview of the theory behind evaluating taxes on new technologies. Section 3 describes the industry and the data and estimates the demand curves. Section 4 presents a conventional tax analysis. Section 5 then estimates the fixed costs of entry into new markets and adds an analysis of how taxes affect diffusion in this market and the ways that changes the main tax results. Section 6 concludes. 


\section{Theory}

The basic idea of why taxes might have a different impact when there are new goods rests on the existence of fixed costs and follows on the insight of Romer (1994) that tariffs can have large negative welfare effects if they lead to fewer goods being imported into a small country.

Consider the market for broadband where the supplier has market power as in Figure $1 .{ }^{4}$ In a conventional analysis of taxes in such a market, imposing a tax will reduce the quantity and create a deadweight loss that depends on the elasticity of demand (see Sumner, 1981 for a traditional exposition). Without taxes, the supplier sets marginal revenue equal to marginal cost and produces $\mathrm{Q}_{0}$ which it sells to consumers at $\mathrm{P}_{0}$. A per-unit tax on the seller, this raises the marginal cost curve to the dashed line in the figure. The after tax price to the buyer rises to $\mathrm{P}_{\mathrm{T}}$ and the quantity falls to $\mathrm{Q}_{\mathrm{T}}$. The government raises revenue equal to area $\mathrm{D}$ from this tax. The consumer surplus after the tax falls from $A+B+E$ to just $A$. The producer surplus goes from $C+D+F+G$ to $B+C$. The $D W L$ of the tax is the entire area of lost consumer and producer surplus, net of taxes: $E+F+G$. To compute the incidence, one simply compares the increase in consumer prices $\left(\mathrm{P}_{\mathrm{T}}-\mathrm{P}_{0}\right)$ to the amount of the tax to get the consumer share.

But now think of a world in which there are many potential markets such as the one presented in figure 1. They have different sizes and before the firm can produce in the market, it must first decide whether to enter at all. If it does so, the firm must pay some fixed cost FC. Without a tax, a firm will enter if the producer surplus in the market, $\mathrm{C}+\mathrm{D}+\mathrm{F}+\mathrm{G}$, exceeds $\mathrm{FC}$. After the tax, though, the potential producer surplus in the market is just $\mathrm{B}+\mathrm{C}$. So long as $\mathrm{B}+\mathrm{C}$ stays greater than $\mathrm{FC}$, the firm still enters the market and the conventional tax calculation is correct. Wherever $\mathrm{C}+\mathrm{D}+\mathrm{F}+\mathrm{G}>\mathrm{FC}$ $>\mathrm{B}+\mathrm{C}$, however, the tax reduces producer surplus enough to prevent entry.

papers relate mainly to dial-up Internet access so are less relevant to the issue of rolling out broadband. 4 At the time of this sample, residential broadband was provided almost exclusively by local cable monopolies. Faulhaber and Hogendorn (2000) show that for almost all realistic levels of demand growth that providers might 
The DWL from the tax in those markets equals the entire producer and consumer surplus. This certainly has the potential to be large, since the entire surplus in a market usually dwarfs a traditional DWL triangle, but the practical importance of this kind of efficiency cost depends entirely on the actual magnitude of the fixed costs and the number of places that might be on the margin of being bypassed. This paper will use the case of broadband at an early point in its diffusion to illustrate that, in practice, the idea may be quite important indeed.

The incidence of the tax in figure 1 will also be changed. Rather than compute the consumer share of the burden as the change to after tax prices relative to the size of the tax, as in the standard approach, one ought to also account for the losses in markets that are bypassed just because of the tax. To the extent that new goods generate large consumer surplus but only modest producer surplus (in excess of the fixed costs), the incidence will tend to be borne significantly more by consumers than in the typical estimate.

\section{Industry Background and Data on the Demand for Broadband}

\section{A. Broadband and Cable Modems}

Broadband, and specifically cable modems allow Internet users to receive data from the Internet over their fiber-optic cable line rather than over conventional telephone wires. This allows the user to access the web at speeds up to 100 times faster than standard dial-up modems. At the time of this sample broadband accounted for only 2-3 percent of online users (Mines, et al., 1998; Strategis Group, 1999), but was growing rapidly. The subscriber base grew from less than 40,000 in 1996 to about 750,000 by mid-1999, and analysts at the time forecast that by 2002 or 2003 , the number of

broadband users could range between 4 million and 27 million (Mines et. al, 1998; Kinetic Strategies, 1999; Kasrel et al., 1999; CATC CyberLab, 2000; Gillett and Lehr, 2000). The actual number in 2002 was 20 million (C.B.O., 2004).

have made at the time, there would be oligopoly at the least. 
Although the major current residential competitor to cable modems is DSL, a service provided over telephone lines, at the time of this sample residential DSL had extremely limited availability (see Gillett and Lehr, 2000). Indeed, even now, cable modems continue to have a dominant market share of residential customers. At the time of the sample in this paper, cable modems were widely regarded as the superior consumer choice (PC World, 1999). For purposes of analyzing the broadband entry decision circa late 1998/early 1999, the local cable monopoly can be viewed as, effectively, having a local monopoly on residential broadband access. The typical fee for broadband access through a cable modem at the time of the survey was about $\$ 40$ per month.

In considering the cost structure of the cable modem industry, it is important to note that the standard marginal cost in the sense of the cost of providing an additional minute of access, is close to zero. The marginal costs facing the system are best thought of as marginal costs per customer rather than per minute. Fixed costs, in this setting, will be costs that are shared across customers in the same metropolitan area. For a cable company to provide service in an area, they must incur the fixed cost of entering the market and then a one time marginal cost for each household that signs up for the service. From those subscribers, then, the cable company receives a flow of revenue. For simplicity, I will sometimes compute this as a lump-sum NPV equivalent assuming that the cable company has a 10 percent discount rate and expects to have the customer for five years at current prices, after which time the cable company gets nothing_either new technology makes the current cable modems obsolete or new competitors drive profits to zero. The choice of discount rate and customer life makes virtually no difference to the main results.

In practice, the marginal costs of adding a customer include the installation and upgrade of the coaxial cable "drop" to the individual home, at least some part of the customer acquisition costs, customer premises equipment (cable modem, etc.), and whatever expected maintenance might be required. In total, JP Morgan (2001) estimates this to be between $\$ 600$ and $\$ 1200$ in 2001. Gillett (1995) suggest that just the engineering cost side was likely to be greater than $\$ 2000$ in 1995 . Owen 
(1999) and Carriere (2001) also report costs somewhere between these estimates. So these per customer costs could be considerable at the time of the sample in late 1998.

The fixed costs include all costs shared over multiple customers in the same market including upgrading the shared cable line to be two-way and digital, upgrading the head-end electronics, the costs of extensive marketing efforts, the costs of establishing and operating a new type of billing and a customer care center, among others (though some of these costs would be incurred anyway if a cable system upgraded to digital in order to compete with satellite, as I will discuss later). The size of these fixed costs can be quite substantial and they are the reason that cable providers do not offer cable modem service to any customer willing to pay for the marginal costs of hooking up their individual home. They must get a large enough group of subscribers to make it worthwhile to enter a market. These fixed costs are the key to understanding the impact of taxation in an innovative industry.

There may be some costs that are not marginal in the sense of being per customer but nor are they fixed across the entire city. Cable companies might have fixed costs at a smaller level than citywide, for example, if they were going to upgrade part of their local networks or something like that. In this sense, the most accurate model might be to look at markets at the neighborhood level rather than at the city level. Practically speaking, the data are not sufficient to allow a more detailed geographic analysis. That said, many of the fixed costs will be at a broader level than the neighborhood and in most urban areas, upgrading the network involves the expensive digging up of the street to get to the cable lines. There are some definite economies of scale to doing such work simultaneously rather than piece by piece. It is also expensive to have part of the network being modern and part being antiquated so companies tend to upgrade most everything at one time. A general piece of evidence supporting the idea of fixed costs at a broader level than just the neighborhood is that although there were some pilot programs testing broadband in limited areas, cable companies in large markets typically offered service to a large number of areas and they did not offer any service in smaller metro areas even if there were small pockets of potential highly educated, 
high-income customers. Indeed, outside of the top 50 metro areas, virtually no company offered residential broadband whatsoever.

\section{B. Data}

To estimate the impact of taxes in this market, I combine several sources of data. The availability of cable modems at the time of the survey (late 1998) comes from PC World (1999). It is important to note that entry at that time was less dramatic than today. When cable companies introduced capacity, take-up rates were typically very low-around 3-5\%. While it would be preferable to model the entry into smaller geographic units than the metropolitan area, the data do not allow it.

Next, I match the PC World data to individual level data on people's willingness to pay for broadband as given in the surveys of Forrester's Technographics 1999 program. Forrester is a leading market research company which studies the information economy. Each year it conducts a survey of close to 100,000 people about their usage of various products as well as demographic information. More detail on the Forrester survey can be found in Bernhoff et al. (1998). The precise question involved asks how much the consumer would be willing to pay (in dollars per month) for high-speed Internet access up to 100 times faster than on conventional modems. Their answers are of the form "Less than $\$ 5 ", " \$ 5-\$ 15 ”, " \$ 15-25 ”$, and so on, up to “\$65+." Summing these individual demand curves in each of the top 69 metro areas gives market level demand curves even for markets where there is no broadband access yet. These 69 areas account for approximately $75 \%$ of the U.S. population. I will use only people reporting reservation prices of at least $\$ 15$ per month to keep those people with reservation prices far from the equilibrium prices from influencing the shape of the estimated demand curve.

Although these demand curves are not based on transactions data, such transaction data has limited value for calculating consumer surplus. One wants to know the area under the entire demand 
curve and transaction data estimate the demand curve only in places near the equilibrium. One typically extrapolates a functional form out to the price axis to make the welfare calculation. Here, rather than assume a functional form from the demand around the equilibrium points, the demand curve will take the functional directly from the respondents' stated preferences. To verify that the stated preferences also match the observed transaction data in the range surrounding actually observed prices I will present several independent pieces of confirmatory evidence.

\section{The Demand Curves}

As an example of the market level demand curves, Figure 2 presents the results from the San Francisco metropolitan area. There are 69 such curves: one for each market. Price per month is on the vertical axis and the number of respondents who would purchase broadband at that price is on the horizontal axis. As there are 1,680 respondents from the Bay area and 2.4 million households in that market, each respondent represents about 1410 households (Nielsen, 1999).

For each of the markets, I then fit a quadratic inverse demand curve to the data and use that equation for the tax analysis..$^{5}$ There was no qualitative difference for the results from using a log linear demand curve and capping reservation prices at the highest reported level or from using a piecewise linear demand curve. ${ }^{6}$ The demand curve estimated for the San Francisco metro area, for example is

$$
\mathrm{P}=\underset{(5.63)}{57.15-.2814 \mathrm{Q}+.0839) \quad\left(.00044 \mathrm{Q}^{2}+\varepsilon\right.} \quad \mathrm{R}^{2}=.90, \mathrm{n}=6
$$

\footnotetext{
5 These demand estimates will not include prices of dial-up Internet service. Although this would seem to be an important substitute for broadband, the data do not bear this out. In independent merger cases where they evaluated the evidence on the subject, both the Department of Justice and the FCC have ruled that the two are separate markets (FCC, 2001; U.S. Department of Justice, 2001). Using micro data, Rappoport et. al (2001) estimate the cross-price elasticity of broadband demand with respect to dial-up price and find it to be miniscule (elasticity of broadband only 0.02 ).

6 I will use the quadratic rather than the piecewise linear because it is easier to deal with and because a standard result from the public finance literature is that the incidence of a tax on a monopolist with a linear demand curve is split evenly between the producer and the consumer. Since incidence is one of the main topics of interest, I did not want to impose linearity. In a previous version of this paper, I also checked the robustness of this functional form by allowing for a log-linear demand curve with a cap on the valuations at the highest stated price. The basic findings about DWL and incidence were the same in that case.
} 
At the market price of about $\$ 40$ per month, the elasticity of demand in San Francisco is 2.65. The elasticities at that price are listed for all of the markets in the first column of table 1 . They range from -2.15 to -3.76 with an average of around -2.75 . The $\mathrm{R}^{2}$ in every equation was quite high. ${ }^{7}$

Several things suggest that these demand curves match well to contemporaneous estimates of broadband elasticities using transaction data. The price elasticity of demand for high bandwidth in the Berkeley INDEX randomized experiments was generally between -2 and -3. Kridel et al. (2000) use cross-city variation in prices to estimate an elasticity of demand for broadband and find it to be about -1.8 at a price of $\$ 49.95$. A previous version of this paper used the price differences for broadband between cable television subscribers and non-cable television subscribers to identify the price elasticity of subscribing to broadband (in markets where it was available at the time of the survey, of course), while controlling for extensive household level demographics. Depending on the specification, the elasticity ranged from -2.8 to -3.5 .

In addition, the reservation price data suggest that among Internet users who live in places without cable modem access, about $4.7 \%$ would be willing to pay more than $\$ 35$ per month and about $2.0 \%$ more than $\$ 45$ per month for broadband access. The actual take-up rates in the data in the areas that did have access (where prices were about $\$ 40$ per month) was about $2.2 \%$ and the take-up rate among those actually having the ability to get access computed in other sources was somewhere between about 3 and 5\% (see Kinetic Strategies,1999 and Gillett and Lehr, 1999).

The match also works well by education level. The share of people in the Forrester data with only a High School education who claim they would pay $\$ 45$ or more for broadband was $1.4 \%$ compared and $3.8 \%$ at $\$ 35$. Kridel et al (2000) show that the actual take-up rate among people with a high-school diploma was comfortably in between at around $2.5 \%$. For people with some college education, $2.5 \%$ say they would be willing to buy at $\$ 45$ and $6.0 \%$ at $\$ 35$. The actual was around $4 \%$.

7 To save space, the tables do not list the coefficients separately for all 69 regressions. These are available from 
Income tabulations also show similarity. In the Forrester data, the share of people earning $\$ 75,000$ or more who would buy at $\$ 45$ was $2.8 \%$ and at $\$ 35$ was $6.3 \%$. In the transaction data, where the market price was in between those two levels, the actual adoption rate was $5.5 \%$. For people earning $\$ 45-75,000,1.9 \%$ would buy at $\$ 45$ and $4.8 \%$ at $\$ 35$. The actual data put the take-up at $3.2 \%$. Given the rather tight match of these results with the ones using transaction price data, I will take the reservation price information in the survey data as accurate.

\section{Equilibrium and a Conventional Tax Analysis}

From these demand curves, if all the top 69 markets in the United States had broadband access at the time of the sample, aggregate demand in late 1998 would be about 1.6 million households. The market price for each market comes from assuming the local cable monopolies have constant marginal cost and price in a Bertrand manner according to the standard monopoly mark-up formula. The average elasticity in markets that actually had cable modem access at the time of the sample was -2.75 and the average actual market price was approximately $\$ 40$. This implies a MC of about $\$ 25$ per month or $\$ 300$ on an annualized basis. This is in the same ballpark as the actual percustomer costs described in Owen (1999) and very close to the cost estimates in Carriere et al. (2000). I will assume it to be equal across markets.

Given this marginal cost, the quadratic inverse demand curves imply a marginal revenue function in each market. Setting the two equal yields the quantity sold and plugging into the demand curve yields the market price. In the calculations here, the projected market prices across areas form a relatively tight band around $\$ 39.50$ per month. This prediction comports well with reality in that there was not much actual variation in prices of existing broadband services across markets at the time of the sample.

The consumer surplus and producer surplus in each market, as derived from the estimates, are

the author upon request. 
listed in the second and third columns of Table $1 .^{8}$ There are 69 but the table lists only the top 50 markets to save space. Summed across all the markets, the total consumer surplus adds up to about $\$ 955$ million per year (restricting to only those markets that actually had service at the time of the survey, the total was $\$ 667$ million).

Using this demand and cost set up, a standard tax analysis is straightforward. Although the Internet Tax Freedom Act forbid the states from applying sales tax to internet access, we can explore the impact of a tax of that magnitude in these data. The median state sales tax at the time was $5 \%$ which would correspond to something like a $\$ 2$ per month tax on a $\$ 40$ per month service. To avoid any complications associated with the differences between ad valorem and specific taxation, let us consider the simplest form of the tax, a $\$ 2$ per month Internet access tax paid by the cable company which is the equivalent of raising the marginal cost from $\$ 25$ to $\$ 27$ per month. Solving for the equilibrium in each market, this would raise the average equilibrium price to $\$ 40.60$ from $\$ 39.50$ (differently in each market, of course). The share of the tax born by consumers in different locations ranges from 50 to $60 \%$. After the tax, the total quantity summed across all the markets falls from 1.63 million to 1.51 million. The total revenue raised from the tax ( $\$ 2$ per month for every customer) yields an annual revenue of about $\$ 36$ million. The new consumer surplus falls by about $\$ 80$ million to $\$ 875$ million per year and producer surplus falls about $\$ 20$ million to $\$ 250$ million. The net $\$ 64$ million drop in social surplus is the deadweight loss and it amounts to more than $180 \%$ of the revenue raised by the tax. This large efficiency cost arises because of the large elasticity of demand at equilibrium prices.

\section{Fixed Costs and Adjusting the Tax Analysis to Account for Technology Diffusion}

This was not a conventional market, however. It was a rapidly growing one where most communities did not yet have access. With fixed costs of entering a market the conventional

\footnotetext{
8 To get the numbers into comparable units, I will weight each city by the average number of households per
} 
approach can miss a great deal. Looking at the producer surpluses in table 1, it is clear that they vary greatly across locations depending on the elasticity of demand and the size of the market. The largest potential producer surplus-New York City with $\$ 23.2$ million-is much larger than the median market's producer surplus, for example, of only about $\$ 2.5$ million. With fixed costs of entering a market, the chances the cable company will wait to rollout service until demand grows further are high. At the time of the sample more than $90 \%$ of markets with producer surplus in the top 20 had access to broadband while less than $30 \%$ of markets ranked 50 and below did. ${ }^{9}$ This is certainly suggestive evidence that fixed costs played an important role in the diffusion of the product. If the fixed costs were only at the neighborhood level, for example, then the diffusion pattern would tend to be small roll outs into the high-income, highly educated neighborhoods in all markets rather than more extensive rollouts in large markets and no service in the small ones.

\section{A. Estimating the Size of the Fixed Cost}

To estimate the fixed cost of serving a market, table 2 lists the results from probit regressions of whether the metro area had access to cable modems at the time of the survey as a function of the producer surplus. This treats the entry as a binary variable at the market level for two reasons. First, the share of people with the service seem relatively similar across markets that have access so it seems like the size of entry must be fairly similar (relative to the overall market size). Second, the data do not allow more detailed geographic analysis of the entry. With this in mind, there were a few metro area where cable modems were available in only one small neighborhood or as part of a limited pilot program-i.e., not generally of the same size as the more general entry locations. I do not count these as entry in the Probit because in such circumstances the provider would not yet have incurred the

survey respondent (about 1220 on average).

9 I restrict the sample to the top 69 metro areas so as to have enough observations to estimate the demand curves in each one and because in these markets almost none of the population lacks access to cable the way some people do in very rural areas. The principle holds even more so in the markets below this top 69 group, however, since virtually none of them had access to broadband at the time of the sample. 
major city-wide fixed costs mentioned above.

The cable modem providers were, effectively, monopoly providers of residential broadband (recall that DSL was hardly available in any location at the time) so the regression will, arguably, not require adjustments for strategic behavior as in Bresnahan and Reiss (1990; 1994) or Berry (1994). A direct measure of the fixed cost of entering the market can be computed by just dividing the constant term by the coefficient on producer surplus (since it is a cost, it is a negative number). This measure gives the dollar value of producer surplus past which the probit index is greater than zero. In other words, it indicates how high the annual producer surplus needs to be in a market before they are predicted to have broadband. The first column uses only the measure of consumer surplus and the constant term in the regression. The imputation predicts about 75 percent of markets correctly (about 5 percent of the time a market did not have access when the model predicted it would and 20 percent of the time a market had access but was predicted not to). The value of the fixed cost here is the same in every market. It suggests that entry does not occur until the annual producer surplus exceeds about $\$ 3.4$ million per year. ${ }^{10}$ This would correspond to a fixed cost of about $\$ 16.4$ million in NPV terms at the discount rate and customer life discussed above. So a market needed to generate as much surplus as somewhere like Pittsburgh, Pennsylvania or Austin, Texas to warrant entry in 1998.

Columns 2 and 3 of the table allow a more nuanced estimate of the fixed costs by allowing for reasonable variation in costs across locations. Column 2 recognizes that higher population density could reduce the costs of rolling out broadband in a market and could reduce the fixed cost of entry. By adding population density (as measured by Census Bureau, 1996) to the regression, the specification asks what level of producer surplus is needed to justify entry but allows the level to be lower if the market is highly concentrated. In the data, however, the density variable itself is

10 Of course the absolute value of the fixed cost depends on the assumptions in the NPV of revenue calculation. The calculation of which cities are on the margin, however, and the additional DWL in those cities relative to the conventional will not be affected by that choice because they are computed as a share of revenue. Changing the NPV assumptions will adjust the implied producer surplus, implied fixed cost and future tax revenue by the same proportion. 
completely insignificant, small, and of the wrong sign. Column 3 repeats the same exercise but uses the growth rate of population in the metro area in the preceding decade, since a location with the same current producer surplus but a higher growth rate of population might lead the cable company to incur the fixed cost and enter the market. Here the variable is the correct sign and is of more consequence but the coefficient is only borderline significant. That said, this does generate a range of implied fixed costs across markets. They range from cities needing current annual producer surplus of only $\$ 2.1$ million to warrant entry in markets at the 90th percentile of population growth to almost $\$ 5$ million at the 10th percentile. Whether one uses the fixed costs from column 1 or column 3 will not change the results, as demonstrated below. I also tried variables that might influence the demand or cost of upgrading the cable lines such as the mean education in the market or the share of people in the market who subscribe to satellite television. More education is typically associated with faster adoption rates for new technology (Goolsbee and Klenow, 2002). Competition from Direct Broadcast Satellite services like DirecTV, which are digital and have very high picture quality, was viewed by many as forcing the most threatened cable systems to upgrade their networks irrespective of the demand for broadband (see the discussion in Goolsbee and Petrin, 2004). When a company upgrades its system, it is much cheaper to provide broadband service as an additional feature. Neither of these factors had any significant effect on the observed deployment rates, however. The results indicate that there is somewhat robust evidence that there some important fixed costs facing the providers of residential broadband.

\section{B. Computing the Actual Deadweight Loss from Taxing New Technology}

If the fixed cost of entry to a market is the size indicated above, the standard analysis of taxation will be highly misleading. The conventional analysis of taxation is only accurate in markets where producer surplus after taxes is sufficient to cover the fixed cost (or in places where they have 
already entered). ${ }^{11}$ These markets together account for about $46 \%$ of the U.S. population. Similarly, there is no problem in the smallest markets since the tax on broadband access has no effect of any kind in places where entry would not occur regardless of the tax rate.

In the middle markets, however, the impact of taxes on diffusion makes a big difference. In these estimates, there were four market where the producer surplus with no tax on access would warrant entry but the surplus with a tax on access would not warrant entry. These were Miami, Cleveland, Tampa, and Milwaukee. If the government had put a tax on broadband (and did so before diffusion took place) the firms would delay entering. In the interim, all of the consumer surplus and producer surplus (but minus the fixed cost of entry) in these markets will become deadweight loss from the tax. ${ }^{12}$

At least in this case, that adjustment makes a big difference. In the 19 markets served both before and after the imposition of the tax (where the conventional tax analysis is completely correct), the sum total of DWL from the tax is $\$ 43$ million per year and the revenue is $\$ 23$ million per year. In just the four markets where entry is delayed because of the tax, however, the DWL arising from lost consumer surplus is $\$ 56$ million—greater than the DWL in the 19 'normal' markets combined. The lost producer surplus (minus the fixed costs) adds an additional DWL of $\$ 14$ million. Thus the deadweight loss adjustment associated with the impact of taxes on diffusion, $\$ 70$ million, exceeds the conventional deadweight loss by a factor of 2 (raising the total DWL from around 180 percent of revenue to 434 percent of revenue).

This finding of dramatically higher DWL from taxation is robust to how one defines the marginal markets. Above, the analysis relied on the hard $\{0,1\}$ entry cutoff and counted only four markets as being delayed for certain and the ones above the threshold as having broadband for certain. Using, instead, the continuous variable of the predicted probability of entry from the Probit

11 Though the producers must now subtract off the fixed cost of entry in each market when computing their total profit, of course.

12 This is similar to the argument made in Faulhaber and Hogendorn (2000) and Owen and Rosston (1998) that 
regression and recomputing the DWL and revenue for each market and summing across markets, weighting by that probability before and after the imposition of a tax, the total DWL as a share of revenue was even higher at 515\%. Accounting for the fact that some markets might be growing faster than others and might induce entry even if the 1998 level seemed insufficient by using the results from the modified entry probits and repeating the same analysis yielded a smaller (but still dramatically larger than in a conventional analysis) DWL of $346 \%$ of revenue.

\section{The Actual Incidence of Taxing Broadband}

The conventional analysis does not just understate the DWL of taxing new goods. In terms of incidence, it also significantly understates the share of the tax ultimately borne by consumers. Typically, the share of the tax borne by consumers is calculated by comparing the pre-tax to the posttax consumer price. This will completely miss the problem arising in the bypassed markets. In those places, consumers bear a large burden from taxation since they lose all of their consumer surplus even though the tax collects no revenue. They are invisible because the tax shuts the market down. This will disproportionately hurt consumers because in the marginal markets, almost by definition, the suppliers were close to indifferent between entering and incurring the fixed cost and choosing not entering. The tax leads producers to lose a small amount by choosing to delay entry and forgoing the small net profit from the market but leads the customers to lose a great deal because of the lost consumer surplus. ${ }^{13}$

In the case of broadband, the overall burden of the tax calculated the conventional way shows that the average price before tax went from $\$ 39.50$ to $\$ 40.60$, suggesting that consumers pay about 55 percent of the $\$ 2$ tax. Accounting for the bypassed markets, however, the total burden of taxation on

forcing universal access to cable modems could slow deployment in medium sized markets.

13 I am indebted to Don Fullerton for pointing out that this argument arises because the monopolist is not able to perfectly price discriminate. If the monopolist could do so, they would capture all the consumer surplus in the market and would, therefore, internalize the impact that their decision to bypass a market has on the small number of high valuation customers. 
producers and consumers (equal to revenue paid plus the lost consumer and producer surplus minus fixed costs) is $\$ 136$ million on an annual basis. Of that $\$ 136$ million, 70 percent $(\$ 93 \mathrm{~m})$ is borne by the consumers. The standard calculation understates the consumer share substantially because it disregards the large losses to consumers in the markets where entry gets delayed. ${ }^{14}$

\section{Conclusion}

This paper argues that the deadweight loss from taxing a new technology that has fixed costs associated with adoption can be much higher than taxing a conventional good because it can lead to a delay in adoption and a subsequent loss of consumer and producer surplus. The paper uses empirical evidence on the market for broadband at an early stage of its development as an empirical illustration that the conventional DWL calculation of a tax can, in practice, understate efficiency losses from taxation by a factor of 2-3 and understate the share of the tax burden borne by consumers by 15 percentage points. Given the importance attached to new goods in recent work in industrial organization and macroeconomics, the findings in this paper suggest that taking into account the impact of taxes on innovation and technology may be fundamental for understanding the role of government policy in the new economy.

14 This also raises the possibility that a subsidy (negative tax) could generate an overall welfare gain to society if it increased consumer surplus in markets where it induced entry by enough to outweigh the normal DWL. See Goolsbee (2002) for a discussion. 


\section{REFERENCES CITED}

Beckert, Walter (2005): Estimation of Heterogeneous Preferences, with an Application to Demand for Internet Services, Review of Economics and Statistics, 87(3), 495-502.

Bernhoff, Josh, Shelley Morrisette, and Kenneth Clemmer (1998), "Technographics Service Explained," The Forrester Report, January, 1(0).

Berry, Steven (1992), "Estimation of a Model of Entry in the Airline Industry," Econometrica; 60(4): 889-917, July.

Bleha, Thomas (2005), "Down to the Wire," Foreign Affairs, May/June.

Bresnahan, Timothy and Roger Gordon, eds (1997), The Economics of New Goods. University of Chicago Press (Chicago, IL).

Bresnahan, Timothy and Peter Reiss (1991), "Entry and Competition in Concentrated Markets," Journal of Political Economy 99(5): 977-1009, October.

Bresnahan, Timothy and Peter Reiss (1994), "Measuring the Importance of Sunk Costs," Annales d'Economie et de Statistique, 0(34): 181-217, April-June.

Bruce, Donald, William Fox, and John Deskins (2004), "Has Internet Access Taxation Affected Internet Use? A Panel Data Analysis," Public Finance Review 32(2): 131147, 2004.

CATV CyberLab (2000), "Stats/Projections," < http://www.catv.org/frame/cmm_market.html>, accessed 11/1/2000.

Carriere, Richard, John Rose, Luc Sirols, Nicolas Turcotte, and Christian Zabbal (2000), "Broadband Changes Everything," Future Intelligence, 6-15, McKinsey and Company.

Compaine, Benjamin (2001), editor, The Digital Divide: Facing a Crisis or Creating a Myth, MIT Press (Cambridge, MA).

Congressional Budget Office (2004), "Is the United States Falling Behind in Adopting Broadband?" Economics and Budget Issue Brief, February 19,< http://www.cbo.gov/showdoc.cfm?index=5082\&sequence=0 $>$, accessed September, 2005.

Downes, Tom and Shane Greenstein (2002), "Universal Access and Local Internet Markets in the US," Research Policy, vol 31, 1035-1052.

Faulhaber, Gerald and Christiaan Hogendorn (2000), " The Market Structure of Broadband Telecommunications," Journal of Industrial Economics, 48(3), September, 305-329.

F.C.C. (2001), Memorandum Opinion and Order, Application to Transfer Control of Licenses by Time Warner Inc and America Online Inc, CS Docket No. 00-30, January 22, < http://ftp.fcc.gov/Bureaus/Cable/Orders/2001/fcc01012.pdf>, accessed August 30, 2002.

Feenstra, Robert (1995) "Estimating the Effects of Trade Policy," In Gene Grossman and Ken Rogoff, Eds. Handbook of International Economics, Volume III (Elsevier, Amsterdam).

Gillett, Sharon (1995), "Connecting Homes to the Internet: An Engineering Cost Model of Cable vs. ISDN," MIT Thesis, Telemedia, Networks and Systems Group, Laboratory for Computer Science.

Gillett, Sharon and William Lehr (1999), "Availability of Broadband Internet Access: Empirical Evidence," presented at 27th Annual Telecommunications Policy Research Conference, Sep 
25-27th, 1999

Goolsbee, Austan (2000), "In a World Without Borders: The Impact of Taxes on Internet Commerce," Quarterly Journal of Economics, May, vol 115(2), pp. 561-576.

Goolsbee, Austan (2001), "The Implications of Electronic Commerce for Fiscal Policy (and Vice Versa)," Journal of Economic Perspectives, Winter 2001, 15(1) 13-24.

Goolsbee, Austan (2002), "Subsidies, the Value of Broadband, and the Importance of Fixed Costs," in Broadband: Should we Regulate High-Speed Internet Access?, Robert Crandall and James H. Alleman, eds. 2002, 278-294, Brooking Institution Press (Washington, D.C.).

Goolsbee, Austan and Jonathan Guryan (2006), "The Impact of Internet Subsidies for Public Schools," forthcoming, Review of Economics and Statistics.

Goolsbee, Austan and Peter Klenow (2002), "Evidence on Learning and Network Externalities in the Diffusion of Home Computers," Journal of Law and Economics, October 2002, Vol XLV (2, part 1), 317-344.

Goolsbee, Austan and Amil Petrin (2004), "The Consumer Gains from Direct Broadcast Satellites and the Competition with Cable TV," Econometrica, vol. 72, no. 2: 351-381.

Hausman, Jerry (1999), "Cellular Telephone, New Products and the CPI," Journal of Business and Economic Statistics; 17(2): 188-94, April.

Hausman, Jerry (1998), "Taxation by Telecommunications Regulation," Tax Policy and the Economy, 12, James Poterba, ed. MIT Press, Cambridge.

Hausman, Jerry (1997), "Valuing the Effect of Regulation on New Services in Telecommunications," Brookings Papers on Economic Activity; Microeconomics, 1-38.

Hoffman, D.L., Novak, T.P., \& Schlosser, A.E. (2000), “The evolution of the digital divide: How gaps in internet access may impact electronic commerce," Journal of Computer-MediatedCommunication, 5(3).

JP Morgan Equity Research (2001), "Broadband 2001: A Comprehensive Analysis of Demand, Supply, Economics, and Industry Dynamics in the U.S. Broadband Market," joint study with McKinsey \& Company, April 2, New York.

Kasrel, Bruce, with Christopher Mines and Karen Koplis (1999), "From Dial-Up to Broadband," Forrester Report, April 1999.

Klenow, Peter and Andres Rodriguez-Clare (1997), "Quantifying Variety Gains from Trade Liberalization," Mimeo, University of Chicago, G.S.B.

Kinetic Strategies (1999), "Commercial Cable Modem Launches in North America," $<$ http://www.cabledatacomnews.com/cmic/cmic7.html>, accessed 7/5/1999.

Kridel, Donald, Paul Rappoport and Lester Taylor (2002), "The Demand for High-Speed Access to the Internet: The Case of Cable Modems," in Forecasting the Internet: Understanding the Explosive Growth of Data Communications, ed. by D.G. Loomis and L.D. Taylor, Kluwer Academic Publishers, Dordrecht.

Mackie-Mason, Jeffrey, and Hal Varian (1995),"Pricing the Internet" in Public Access to the Internet, Brian Kahin and James Keller, eds. (MIT Press; Cambridge).

Mazerov, Michael (2003), "Making the Internet Tax Freedom Act Permanent in the Form Currently Proposed Would Lead to a Substantial Revenue Loss for States and Localities," Center on Budget and Policy Priorities report, October 20, < http://www.cbpp.org/10-20- 
03sfp.pdf>, accessed December, 2005.

McKnight, Lee and Joeseph Bailey (1997), Internet Economics. (MIT Press, Cambridge)

Mines, Christopher, Mary Modahl, and Shar VanBoskirk (1998), "Broadband Hits Home," The Forrester Report 5(4), August.

Nevo, Aviv (2003), "New Products, Quality Changes and Welfare Measures from Estimated Demand Systems," The Review of Economics and Statistics, 21(1), 43-52.

Nielsen Media Research (1999), "Designated Market Areas" <http://www.nielsenmedia.com/ whatratingsmean/dmas.html>, access date September 9, 1999.

Owen, Bruce (1999), The Internet Challenge to Television. Harvard University Press, Cambridge.

Owen, Bruce and Gregory Rosston (1998), "Cable Modems, Access, and Investment Incentives," mimeo Stanford Institute for Economic Policy Research, December.

PC World (1999), “But Can I Get It?” March 1999, p.114.

Petrin, Amil (2002), "Quantifying the Benefits of New Products: The Case of the Minivan," Journal of Political Economy, 110:705-729.

Rappoport, Paul, Donald Kridel, Lester Taylor, Kevin Duffy-Deno, and James Allemen (2003), "Residential Demand for Access to the Internet," Chapter 5 in the International Handbook of Telecommunications Economics, Volume II, ed. G. Madden, Edward Elgar.

Romer, Paul (1994), "New Goods, Old Theory, and the Welfare Costs of Trade Restrictions," Journal of Development Economics, 43: 5-38.

Rosenbush, Steve, Catherine Yang, Ronald Grover, Moon Ihlwan and Andy Reinhardt (2004), "Broadband: What's the Hold Up?" BusinessWeek Online, March 1, <http://www.businessweek.com/magazine/content/04_09/b3872049.htm>, accessed December 2005.

Strategis Group (1999), "Residential High-Speed Internet: Cable Modems, DSL and Wireless Broadband," Mimeo, December 1999.

Sumner, Daniel (1981), "Measurement of Monopoly Behavior: An Application to the Cigarette Industry," Journal of Political Economy 89(5): 1010-19.

Trajtenberg, Manuel (1989), "The Welfare Analysis of Product Innovations with an Application to Computed Tomography Scanners," Journal of Political Economy, 97, 444-479.

U.S. Census Bureau (1996), " Land Area, Population, and Density for Metropolitan Areas: 1990," < http://www.census.gov/population/censusdata/90den_ma.txt>, accessed September 2005.

U.S. Department of Justice (2001), "Competitive Impact Statement," AT\&T merger with Media One, <http://www.usdoj.gov/atr/cases/f4800/4842.pdf>, accessed, August 30, 2002.

Varian, Hal (2000), "Estimating the Demand for Bandwidth," Mimeo, University of California, 


\section{FIGURE 1: TAXATION IN MONOPOLY MARKETS}

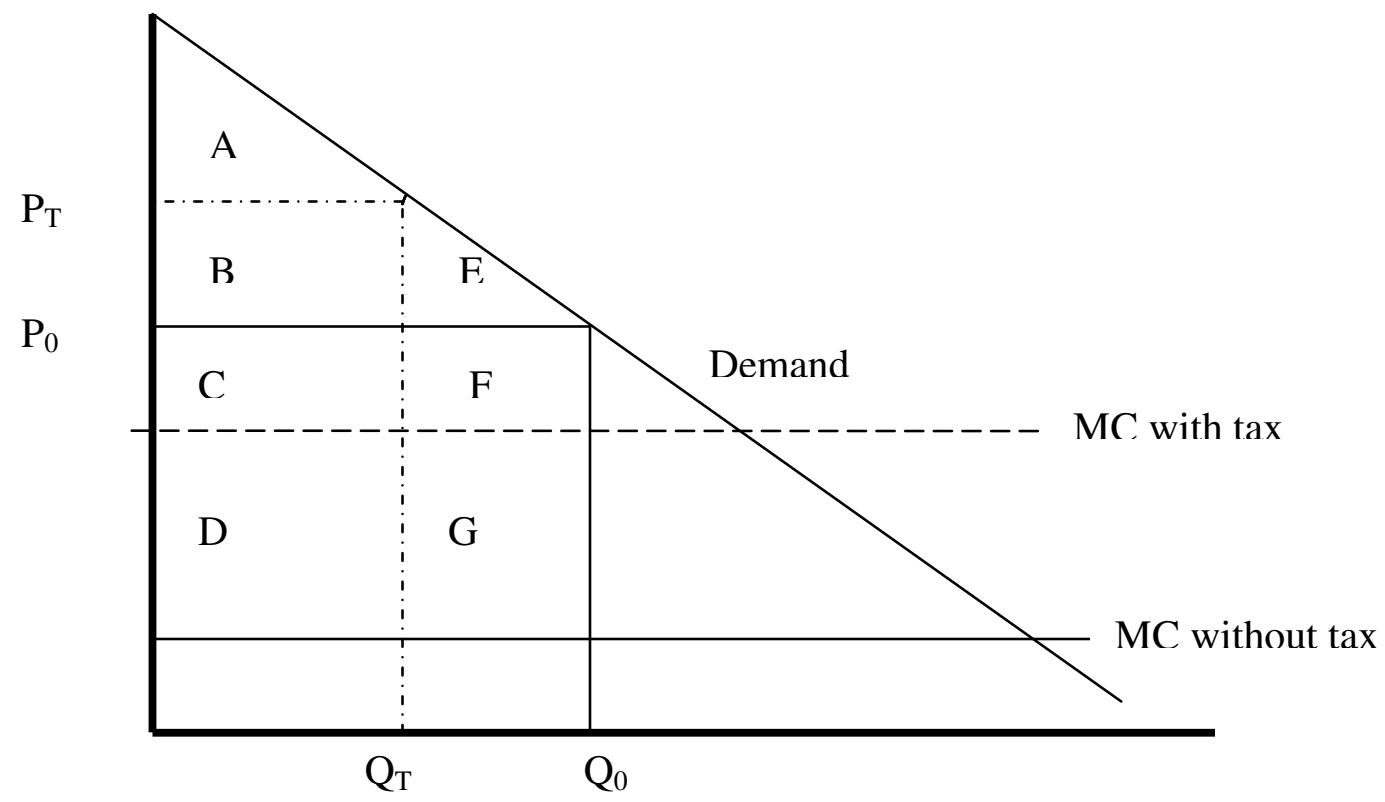

FIGURE 2: DEMAND CURVE FOR BROADBAND IN THE SAN FRANCISCO AREA

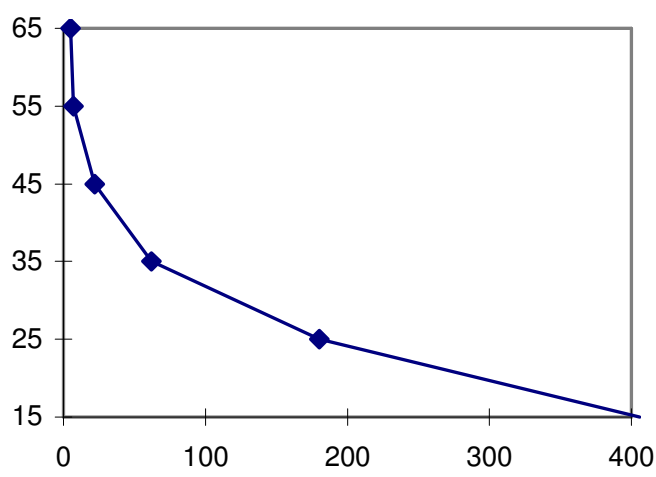

Source: Number of survey respondents who would buy broadband at a given price per month. Computed as detailed in the text. 
Table 1: Demand and Surplus Estimates By Metro Area (in \$000s)

\begin{tabular}{|c|c|c|c|}
\hline Metro Area & Elasticity $(\mathrm{P}=\$ 40 / \mathrm{mo})$ & Annual PS & Annual CS \\
\hline NYC & -2.82 & 22838 & 74348 \\
\hline LOSANGELES & -2.67 & 18531 & 59465 \\
\hline SANFRAN & -2.65 & 14745 & 47270 \\
\hline WASHDC & -2.61 & 13578 & 43293 \\
\hline CHICAGO & -2.59 & 12551 & 39899 \\
\hline PHILLY & -2.75 & 12182 & 39390 \\
\hline DALLAS & -2.59 & 10072 & 32047 \\
\hline BOSTON & -2.81 & 9231 & 30029 \\
\hline SEATTLE & -3.07 & 7761 & 25906 \\
\hline ATLANTA & -2.44 & 7180 & 22425 \\
\hline PHOENIX & -2.30 & 6803 & 20856 \\
\hline DETROIT & -2.87 & 6760 & 22155 \\
\hline HOUSTON & -2.60 & 6290 & 20040 \\
\hline SACRAMEN & -2.66 & 6290 & 20167 \\
\hline MINNEAPO & -3.04 & 5817 & 19337 \\
\hline DENVER & -2.50 & 5497 & 17292 \\
\hline SANDIEGO & -2.90 & 5182 & 17019 \\
\hline STLOUIS & -2.47 & 5064 & 15880 \\
\hline BALTIMORE & -2.82 & 4825 & 15693 \\
\hline MIAMI & -2.49 & 4320 & 13573 \\
\hline CLEVELAND & -2.96 & 4318 & 14250 \\
\hline MILWAUKEE & -2.54 & 4211 & 13315 \\
\hline TAMPA & -2.89 & 4200 & 13753 \\
\hline NASHVILLE & -2.64 & 3940 & 12604 \\
\hline PORTLAND & -2.74 & 3848 & 12403 \\
\hline RALEIGH & -2.44 & 3781 & 11826 \\
\hline PITTSBURGH & -3.68 & 3609 & 12660 \\
\hline AUSTIN & -2.30 & 3321 & 10201 \\
\hline COLUMBUS & -2.96 & 3174 & 10497 \\
\hline SALTLAKECITY & -2.99 & 3053 & 10100 \\
\hline CINCINNATI & -2.63 & 2868 & 9148 \\
\hline INDIANAPO & -3.45 & 2843 & 9783 \\
\hline ORLANDO & -2.90 & 2797 & 9159 \\
\hline NORFOLK & -3.01 & 2691 & 8910 \\
\hline HARTFORD & -2.31 & 2548 & 7816 \\
\hline BUFFALO & -3.08 & 2391 & 7972 \\
\hline WESTPALM & -2.78 & 2275 & 7389 \\
\hline ALBANY & -3.60 & 2260 & 7881 \\
\hline GRANDRAPIDS & -3.24 & 2097 & 7107 \\
\hline CHARLOTTE & -3.06 & 2064 & 6877 \\
\hline PROVIDENCE & -3.05 & 1980 & 6595 \\
\hline SANANTONIO & -2.64 & 1973 & 6303 \\
\hline DAYTON & -3.22 & 1961 & 6624 \\
\hline NEWORLEAN & -3.31 & 1908 & 6513 \\
\hline RICHMOND & -3.02 & 1875 & 6248 \\
\hline TOLEDO & -3.27 & 1801 & 6132 \\
\hline ALBUQUER & -2.71 & 1792 & 5774 \\
\hline KANSASCITY & -2.15 & 1792 & 5376 \\
\hline LANCASTER & -3.50 & 1659 & 5720 \\
\hline
\end{tabular}

Source: Estimates from a quadratic demand curve for each market. These are the top 50 markets, the next 19 markets are excluded to conserve space but are included in the estimates. The elasticity is calculated at a price of $\$ 40$ per month. The producer and consumer surplus calculations are computed as described in the text. 
TABLE 2: Does the Market Have Cable Modem Access in 1998

\begin{tabular}{|c|c|c|c|}
\hline & $(1)$ & $(2)$ & $(3)$ \\
\hline Constant & -.8394 & -.6011 & -1.2024 \\
& $(.2623)$ & $(.3305)$ & $(.3430)$ \\
Producer Surplus & .0120 & .0148 & .0116 \\
Pop. Density & $(.0036)$ & $(.0044)$ & $(.0036)$ \\
Population Growth Rate & & -.0008 & .2603 \\
$\mathrm{n}$ & & $(.0007)$ & $(.1564)$ \\
& & & 69 \\
\hline
\end{tabular}

Notes: The dependent variable in each Probit is whether or not the metro area had general access to broadband in 1998. The producer surplus is calculated as described in the text. The measures of population density and the population growth rate come from the U.S. Census. The implied fixed cost is calculated in NPV terms assuming a discount rate of $10 \%$ and a customer life of five years. 